\title{
Nitrile orientation versus crystal lattice as a tool for tuning the spin crossover properties in the one-dimensional coordination polymers $\left[\mathrm{Fe}(\mathrm{ebtz})_{2}(\mathrm{RCN})_{2}\right]\left(\mathrm{BF}_{4}\right)_{2}(\mathrm{RCN}=$ nitrile)
}

\author{
J. Kusz ${ }^{1}$, M. Książek ${ }^{1}$, M. Kaźmierczak ${ }^{2}$, A. Tołoczko ${ }^{2}$, M. Weselski ${ }^{2}$ R. Bronisz ${ }^{2}$ \\ ${ }^{1}$ Institute of Physics, University of Silesia, Katowice, Poland \\ ${ }^{2}$ Faculty of Chemistry, University of Wrockaw, Wrockaw, Poland
}

joachim.kusz@us.edu.pl

[Zn(ebtz) $\left.)_{3}\right]\left(\mathrm{BF}_{4}\right)_{2}(1,2$-di(tetrazol-2-yl)ethane) was a first example of coordination polymer based of 2-substituted tetrazole as donor group [1]. Expanding studies on Fe(II) complexes showed that species of [Fe(tetrazol-2-yl)6]-type core exhibit thermally induced spin crossover (SCO) [2]. Further researches revealed an ability of 2-substituted tetrazole to the formation of coordination compounds in which metal ion $(\mathrm{Cu}(\mathrm{II}), \mathrm{Fe}(\mathrm{II}))$ is surrounded by four tetrazole rings and two alcohol or nitrile molecules. The complexes of the type $\left[\mathrm{Fe}(\text { tetrazol-2-yl })_{4}(\mathrm{RCN})_{2}\right]$ also exhibit $\mathrm{SCO}$, which can be additionally affected by conformational changes of axially coordinated nitrile molecules [3]. It was established that the presence of a wide hysteresis loop in $\left[\mathrm{Fe}(\mathrm{ebtz})_{2}\left(\mathrm{C}_{2} \mathrm{H}_{5} \mathrm{CN}\right)_{2}\right]\left(\mathrm{ClO}_{4}\right)_{2}$ is related to the reorientation of coordinated propionitrile molecules coupled with significant changes of separation between supramolecular layers [4]. In order to explain the role of coordinated nitrile molecules on spin crossover properties, we have carried out detailed studies depending on systematic exchange of the ones in series of $\left[\mathrm{Fe}(\mathrm{ebtz})_{2}(\mathrm{RCN})_{2}\right]\left(\mathrm{BF}_{4}\right)_{2}[5]$. We have focused on uncommon, very slow spin crossover observed in propionitrile derivatives. Measurements of the temperature dependence of magnetic susceptibility revealed thermal quenching of HS form after rapid cooling of the sample at $10 \mathrm{~K}$. Measurements carried out at very slow scan rates showed an occurrence of hysteretic spin crossover $\left(T_{1 / 2}{ }^{\downarrow}=78 \mathrm{~K}, T_{1 / 2}{ }^{\uparrow}=123 \mathrm{~K}\right)$. It allowed to perform isothermal $(80 \mathrm{~K})$ time-resolved singlecrystal X-ray diffraction studies for the HS $\rightarrow$ LS transition. Initially, it occurs very slow shrinkage of polymeric chains associated with reduced cell volume at 77\% (concerning the difference between cell volumes $\mathrm{V}_{H S}-\mathrm{V}_{\mathrm{LS}}$ ) and only $16 \%$ of iron(II) ions adopt LS form. Then there starts fast and abrupt spin crossover associated with a significant increase of the distance between supramolecular layers, which occurs along the direction of the Fe-nitrile bonds. In this stage, there is a reorientation of propionitrile molecules connected with an increase of Fe-N-C(nitrile) angle from 143.6 to $161.6^{\circ}$. LIESST and r-LIESST studies performed at $14 \mathrm{~K}$ on single crystals confirmed that the contribution of switched Fe(II) ions strongly corresponds to the orientation of the nitrile molecule. These studies showed that stabilization of the spin form, produced by light irradiation, is dependent on the lattice-based effects. This property was utilized to manipulate spin crossover parameters by partial exchange of propionitrile by butyronitrile molecules. These studies showed that an increase in a fraction of butyronitrile molecules involves an increase of Fe-N-C(nitrile) angle resulting in a shift of SCO temperatures to higher values and in reduction of the width of the hysteresis loop.

[1] Bronisz, R. (2002). Inorg. Chim. Acta 340, 215.

[2] Bronisz, R. (2007). Inorg. Chem. 46, 6733.

[3] Książek, M., Kusz, J., Białońska, A., Bronisz, R. \& Weselski, M. (2015). Dalton Trans. 44, 18563.

[4] Białońska, A. \& Bronisz, R. (2012). Inorg. Chem. 51, 12630.

[5] Książek, M., Weselski, M., Każmierczak, M., Tołoczko, A., Siczek, M., Durlak, P., Wolny, J.A., Schünemann, V., Kusz, J. \& Bronisz, R. (2020). Chem. Eur. J. 26, 14419.

Keywords: spin crossover, time-resolved X-ray studies, coordination polymer, Fe(II) complexes, tetrazoles 